\title{
Sintagma Dalam Cerpen “Jaket“ Ayah Karya Eep Saefulloh Fatah Dengan Perspektif Semiotik Sastra
}

\author{
Andika Hendra Mustaqim \\ Akademi Bahasa Asing BSI \\ Jln. Salemba Tengah 25 Jakarta Pusat \\ andika.ahq@bsi.ac.id
}

\begin{abstract}
The goal of this research is exploring the syntagm in the short story Jaket Ayah by Eep Saefulloh Fatah. The research method in this research is content analysis. The result and the analysis of the research, the research finds some syntagm elements, the first syntagm is the politician which consist the arrogant political party, the magician, full of theatrics, the traitorous, the tactics, and many promises. Another syntagm is a political party consisting of a cadre crisis, a candidate for leader, a clean person, and a regional head election. Other syntagm is dowry which related to political costs, consolidation and coordination, and extortion. The other syntagm was the other candidate bupati namely imaging, campaign, and famous. The most syntagm is the family which consist attention, affection, and build the future. Next, two very prominent signs are the jacket and the savings. The jacket is a witness in every political event involving the father. Savings funds should be used for the best interests that have been planned from the beginning. A savings fund should be a chapter that must determine a comforting new life rather than troubling and worrying. "Jaket Ayah" was written by Eep Saefulloh Fattah who is a political observer who loves to write stories.
\end{abstract}

Keywords : Syntagm, Literary, Semotics

\section{PENDAHULUAN}

\subsection{Latar Belakang Penelitian}

Politik itu kotor. Tapi, hanya sedikit orang yang mau berbicara tentang kekotoran politik secara jelas. Mereka sadar kalau berbicara terlalu vulgar akan diserang. Dan sastra adalah solusinya. Ketika banyak media massa enggan berbicara tentang kekotoran politik, maka sastralah yang menjadi media paling tepat untuk mengungkapkannya

Sastra tetap dianggap sebagai fiksi dan cerita khayalan, meskipun ide dam cerita yang ditampilkannya adalah fakta dan realitas di masyarakat. Sastra sering dianggap sebagai bualan semata padahal kisah yang disampaikan terkadang benar-benar terjadi di masyarakat.

Cerita pendek atau disingkat cerpen merupakan bagian dari karya sastra. Cerpen umumnya dipublikasikan di koran atau media online setiap akhir pekan. Dan cerpen pun menjadi wahana untuk menuangkan ide tentang kisah-kisah politik dengan balutan fisik yang menggoda.

Di dalam cerpen sebenarmya terkandung bukan hanya pertarungan hegemoni semata. Tak semata peperangan wacana saja. Tapi, dalam cerpen juga terkandung perang tanda.

Di dalam perang tanda, dipastikan cerpen juga mengandung permainan tanda-tanda. Dan tanda itu menjadi kajian menarik dalam sastra karena menyangkut fenomena di masyarakat. Tanda yang terdapat di dalam cerpen juga menjadi kajian menarik karena membutuhkan penafsiran.

Untuk mengungkap tanda dibutuhkan disiplin ilmu yang disebut dengan semiotika. Ilmu itu kajian yang independen. Semiotik dikenal sebagai kajian lintas disiplin ilmu. Sastra juga mengenal tentang semiotika.
Berdasarkan latar belakang tersebut, penulis tertarik untuk mengangkat judul penelitian "Sintagma Pada Cerpen Jaket Ayah Karya Eep Saefulloh Fatah Dalam Perspektif Semiotik

Sastra". Adapun permasalahan atau rumusan penelitian yang diangkat adalah bagaimana sintagma dalam cerpen tersebut, bagaimana semiotik sastra dalam cerpen tersebut, dan bagaimana biografi penulis dalam sudut pandang semiotik sastra.

\subsection{Tinjauan Pustaka}

Tinjauan pustaka akan mengupas teori tentang sintagma dan semiotik sastra. Kedua teori tersebut akan menjadi landasan dalam analisis cerpen.

\subsubsection{Sintagma}

Sintagma menjadi kajian yang kerap melekat dalam pembahasan semiotik. Ketika membahas tentang tanda dalam sudut pandang semiotik, maka tidak bisa dilepaskan dari sintagma.

Chandler (2017:100) mengungkapkan sintagma merupakan kombinasi dari penanda yang berinteraksi dan membentuk makna keseluruhan dalam teks. Kombinasi tersebut dibuat dengan kerangka aturan sintaktik. Dalam bahasa, kalimat, misialnya, merupakan sintagma dari kata-kata. Sintagma sendiri tidak terbatas pada rangkaian. Dalam struktur drama, sintagma juga terdiri dari babak dan adegan.

Shortell (2016:56) menjelaskan sintagma merupakan koleksi tanda yang dibentuk oleh serangkaian unit yang menganalisis untuk mengungkap bagaimana pekerjaan membuat makna. Sebagai contoh, dalam tes komunitas di linguitik, kita akan menanyakan 
jika ada kesempatan hasil ekspresi pesawat dalam koresponden perubahan dalam konten pesawat.

Sangat jelas kalau sintagma terdapat dua pandangan antara Ferdinand De Saussure dan Barthes. Saussure (1964:123-124) dalam Krampen (1987:73) menekankan kalau tindak tutur adalah sintagma, yang dapat dipahami sebagai kombinasi tanda. Kalimat yang dikeluarkan pembicara merupakan bentuk sintagma.

Dalam penelitian ini akan difokuskan pada sintagma dalam sudut padang Barthes. Dipilihnya Barthes dikarenakan pandangannya tentang sintagma lebih tepat dalam menganalisis cerpen.

Barthes (1973:58) menegaskan sintagma merupakan kombinasi tanda yang memiliki ruang sebagai pendukungnya. Dalam bahasa artikulasi, ruang ini bersifat linier dan tak bisa diulang (yang lazim disebut dengan “rantai pembicaraan”). Dua elemen ini tak bisa dilafalkan secara bersama. Masingmasing istilah itu juga menderivasi nilainya dari oposisinya dalam "rantai tindak tutur”.

Barthes (1973:62) menolak penyamaan sintagma dengan tindak tutur dengan alasan: (a) karena sintagma eksis maka penggunaannya dilarang untuk diubah atau untuk mencapai kombinasi bebas tindak tutur, (b) karena sintagma tindak tutur dibentuk berdasarkan bentuk regular yang dimiliki oleh bahasa. Kemudian, Barthes (1973:71) memaparkan kalau sintagma menghadirkan dirinya dalam bentuk rantai/rangkaian (contohnya, aliran tindak tutur). Dengan begitu, makna hanya muncul dari artikulasi atau dari pembagian simultan aliran signifikasi. Sistem mengkonstitusi poros kedua dari bahasa.

Untuk lebih jelas dalam analisis sintagma, Kurniawan (2001:64-65) mengutip Barthes (1967:63) tentang contoh sintagma. Kalau sistem garmen: campuran dari tipe pakaian yang sama dari unsur yang berbeda: rok-blus-jaket. Kalau sistem makanan, sintagma adalah bagian nyata dari hidangan yang dipilih selama makan: inilah menu. Sedangkan sistem perabot adalah campuran dari perabotan yang berbeda dalam ruangan yang sama: tempat tidur-lemari-pakaian-meja, dan lain-lain.

\subsubsection{Semiotik Sastra}

Semiotik digunakan dalam semua lini. Chandler (2017:3) menjelaskan kalau semiotik bukan sebagai satu disiplin ilmu, tetapi melengkapi dalam berbagai disiplin ilmu. Semiotik digunakan oleh linguis, psikolog, sosiolog, analis media dan sastra. Semiotik memiliki kontribusi luas dalam bidang ilmu pengetahuan.

Chandler (2017:3) menutup pendapat Umberto Eco (1976:6) kalau semiotik berkaitan dengan segala sesuatu yang dianggap sebagai tanda. Kemudian, Ferdinand de Sausseure (1916:16) yang menyebutkan kalau semiotik adalah ilmu yang mengkaji kehidupan tanda di dalam masyarakat (Chandler, 2017:3). Diungkapkan Chandler, 2017:3, kalau pakar semiotika itu mencari identifikasi dan kategori kode atau konvensi sesuai dengan tanda yang dibentuk.

Semiotik juga diterapkan dalam bidang sastra. Itu dikarenakan sastra memiliki banyak tanda sehingga menjadi ladang yang subur bagi semiotik.

Simpkins (2001:94) mengungkapkan hal terpenting dalam semiotika sastra adalah sistemik penulis. Dalam semiotik sastra tidak dilepaskan dari biografi penulis, perspektif individu, analisis posisi sosial, dan relevasi sistem sastra.

Veivo, Harri, dkk. (2009:2-3) Semiotik sastra menggunakan pendekatan struktural dan pragmatik yang diklaim memiliki validitas. Itu disebabkan karena bahasa memang melekat dan tidak lepas dari realitas. Bahasa itu sendiri juga mampu mendefinisikan realitas yang diwujudkan dalam dalm sastra. Sedangkan sastra sendiri terikat dengan praktek sosial dan budaya.

\section{METODOLOGI PENELITIAN}

Pendekatan yang diterapkan dalam penelitian ini adalah kualitatif. Sedangkan, metode penelitian yang digunakan penelitian ini adalah analisis isi. Dipilihnya isi karena penelitian ini lebih mengutamakan pendekatan konten di dalam film.

Dalam penelitian ini, data yang digunakan oleh penulis adalah cerpen berjudul “Jaket Ayah” karya Eep Saefulloh Fatah yang diterbitkan oleh Media Indonesia pada 4 Mei 2014.

Dengan data yang telah terkumpul, langkah selanjutnya adalah analisis. Analisis itu berdasarkan dengan pertanyaan penelitian. Berdasarkan hasil analisis, selanjutnya adalah penafsiran dan penarikan kesimpulan. Adapun penafsiran itu berdasarkan teori pengembangan narasi yang menjadi patokan dalam menganalisis. Hasil dari penafsiran tetap mengaju pada teori.

\section{HASIL DAN PEMBAHASAN}

\subsection{Analisis Sintagma}

Unsur sintagma yang dikupas penulis yang pertama adalah politikus partai politik. Cerpen yang ditulis Fatah itu memang membahas tentang pemilihan kepala daerah. Unsur utama dalam partai politik adalah politiku.

Dalam cerpen tersebut, sitagma politikus adalah sombong, tukang sulap, penuh sandiwara, mudah berkhianat, banyak siasat, dan banyak berjanji. Sintagma itu dijabarkan dengan jelas oleh Fatah 
dengan merujuk pada deskripsi langsung bukan dengan melalui dialog. Dengan begitu, pembaca bisa menangkap dengan jelas apa yang dimaksud dengan sintagma tersebut.

Keculasan mengintip di balik sorot matanya. Ekspresi bibirnya menunjukkan betapa gampang ia melecehkan lawan bicara. Bahasa tubuhnya mengingatkanku pada tukang sulap yang menyembunyikan kebohongan lewat gerakan tubuh cepat dan pura-pura berwibawa. Dari cipratan ludahnya ketika berbicara, aku seperti mencium bau pengkhianatan yang sudah disiapkan sebelum perjanjian dibuat. Tapi Ayah tampak tersihir, mengangguk-angguk takzim. (Fatah, 2014)

Sintagma pemimpin politikus dikaitkan dengan bahasa figuratif sehingga menimbulkan efek yang mengena. Misalnya, tukang sulap yang diidentikkan dengan sikap dan omongan penuh kebohongan. Politikus memiliki stiga di masyarakat selalu berbohong karena jarang menepati janji saat kampanye. Politikus juga dianggap sebagai tukang sulap karena apa yang ditampilkan hanya sebagai trik, bukan suatu kesungguhan.

Dikarenakan politikus adalah tukang sulap, maka dia pun akan pandai untuk memikat dan menarik hati orang lain yang menjadi korban tipu muslihatny. Seperti tukang sulap, politikus akan membujuk dan mempengaruhi orang lain agar tunduk dan mau mengikuti apa yang diinginkannya. Tujuannya agar tukang sulap mendapatkan keuntungan besar dan korban akan ditipu.

Maka, yang mereka sebut penggalangan itu bagiku adalah drama menyedihkan yang dimainkan ayahku dengan segenap ketulusannya, dikelilingi politisi yang menebar kepalsuan tanpa malu. Makin lama kemarahan makin menggila di ubun-ubunku, tapi tak pernah meledak karena tertahan oleh rasa hormat dan prihatinku yang mendalam pada ayah. (Fatah, 2014)

Selain pengandaian tukang sulap, Fatah juga menyamakan politikus dengan burung gagak. Padahal, burung gagal adalah simbol kematian. Di masyarakat, ketika burung gagak bertengger di suatu rumah, berarti itu ada kabar kematian yang menimpa anggota keluarga di rumah tersebut.

Dengan penyamaan burung gagak adalah simbol kematian, itu berarti politikus akan membawa kematian kepada siapa saja yang menjadi korbannya. Namun, berbeda dengan burung gagak yang sebenarnya di mana tampil menyeramkan melalui suara dan penampilannya, politikus justru tampil dengan elegan.

Politikus selalu tampil dengan penuh harapan dan selalu memberikan harapan yang muluk-muluk. Dia bersuara seperti layaknya orang yang selalu benar tanpa memberikan ada kesalahan yang ada pada dirinya. Pandangan jauh kedepan tanpa memedulikan risiko kalah dan menang, tetapi selalu berpatokan pada ambisi yang telah dicanangkannya.

Di telingaku, kata-kata bersayap ketua partai itu seperti suara burung gagak yang bersiap menukik menyerbu mangsa. Tapi ayah terkesima, seolah bertemu kata-kata mutiara penuh kebajikan. Pagi itu aku seperti berkenalan ulang dengan ayah. Ternyata Ayah tak sanggup disanjung tinggi. Ayah gampang terbuai oleh rayuan murah, dibungkus ajakan 'berbakti pada negeri'. Ayahku yang kukuh mudah dirobohkan luapan pujian. (Fatah, 2014)

Selanjutnya, sintagma lainnya adalah partai politik yang terdiri dari krisis kader, calon pemimpin, orang yang bersih, dan pemilihan kepala daerah. Partai politik merupakan salah satu elemen paling penting dalam politik. Tanpa partai politik, maka tidak ada politik. Terlalu pentingnya partai politik menjadikan semua orang membutuhkannya.

Untuk menjadi pemimpin suatu negara atau provinsi atau pun kabupaten bahkan kota harus membutuhkan partai politik sebagai kendaraan. Partai politik bukan saja hanya sebagai kendaraan semata, tetapi itu menjadi rumah bagi siapa saja yang ingin menjadi pemimpin.

Namun demikian, partai politik kerap tidak menjalankan fungsinya dengan baik. Salah satu tujuan partai politik adalah kaderisasi. Mereka seharusnya mengkader para anggotanya untuk menjadi pemimpin untuk dicalonkan pada suatu pemilihan kepala daerah atau pemilihan legislatif.

Faktanya, partai politik justru kerap membutuhkan tokoh dari unsur eksternal partai yang mampu mengangkat citra partai. Itu disebabkan banyak tokoh eksternal partai yang justru ditarik oleh partai dalam suatu pemilu. Itu disebabkan mereka mengalami krisis kader.

Sesuai permintaan, aku catat baik-baik semua yang dikatakan lelaki setengah baya dengan wajah bulat dan perut yang lebih bulat lagi itu. Partainya alami krisis kader. Mereka butuh calon pemimpin yang terbukti bersih. Mereka ingin usung ayah sebagai calon bupati. (Fatah, 2014)

Partai politik membutuhkan segala cara untuk berjualan. Salah satu cara yang ditunjukkan adalah 
bagaimana agar jualannya laku di pasaran. Ketika produk yang mereka miliki yakni kader partai politik tidak mampu memenuhi standar dan kriteria untuk bisa dijual di masyarakat, tentunya mereka berusaha sekuat tenaga untuk memenuhi kebutuhan yang sesuai dengan selera pasar.

Dan salah satu selera yang diinginkan pasar adalah pemimpin yang bersih. Itupun dengan segala upaya berusaha dipenuhi oleh partai politik. Mereka pun mencari tokoh yang dinilai mampu sesuai dengan keinginan pasar.

Partai politik akan mencari tokoh yang memiliki rekam jejak yang bersih dan tidak cacat. Meskipun tokoh itu bukan anggota partai dan tak pernah menjadi anggota partai politik, tapi dengan segala cara akan dilakukan partai politik agar tokoh itu mau bergabung dengan partai dan diusung dalam pemilihan kepala daerah.

Pada cerpen berjudul “Jaket Ayah”, tokoh bersih yang menjadi target partai politik adalah Kolonel (Purn) Sangaji Putrandi. Tentunya dipilih militer karena para perwira dan prajurit dikenal sebagai figur yang bersih dan berwibawa. Selain itu, masyarakat juga masih menganggap tokoh militer memiliki jiwa kepemimpinan yang tegas.

Aku kenal ayah. Terlepas bahwa ternyata ia gampang dibikin mabuk oleh sanjungan oleh sanjungan setinggi langit, sepanjang hidup ayah mengabdikan diri untuk Merah Putih. Di akhir kariernya, ayah adalah perwira yang lurus, mantan petarung di medan perang yang dihormati karena integritasnya terjaga. (Fatah, 2014)

Partai politik selalu menjadikan momen pemilihan kepala daerah sebagai pesta untuk mencari pemimpin baru. Mereka melakukan seleksi para calon pemimpin yang memiliki nilai jual di masyarakat. Tentunya, partai politik akan melalui survei dan melihat kandidat yang memiliki peluang untuk menang.

Sebenarnya, ada dua sisi di mana partai politik yang terkadang membutuhkan kandidat. Kemudian, kandidat juga yang membutuhkan partai politik untuk membutuhkan kendaraan. Namun, dalam cerpen “Jaket Ayah”, justru partai politiknya yang mencari kandidat.

Tapi ayah berkeras. Setelah tiga kali para pengurus partai itu berkunjung ke rumah, pertahanan ayah benar-benar jebol. Saat aku perlihatkan kemarahanku karena ayah begitu gampang terbuai oleh rayuan politisi itu, Ayah malah balik marah. (Fatah, 2014)
Sangat jelas kalau dalam cerpen tersebut, pihak partai politik yang sangat membutuhkan Kolonel (Purn) Sangaji Putrandi sebagai kandidat calon bupati pada pemilihan kepala daerah. Berbagai bujuk rayu dilancarkan. Ribuan janji ditawarkan. Tentunya untuk mememangkan pemilihan kepala daerah.

Selanjutnya, sintagma dalam cerpen "Jaket Ayah" yakni berkaitan dengan mahar. Sintagma mahar itu berkaitan dengan biaya politik, konsolidasi dan koordinasi, serta pemerasan. Ketiga unsur tersebut menjadi unsur yang melingkupi mahar.

Mahar merupakan uang pengikat. Umumnya, mahar dikenal dalam pernikahan. Dalam politik, mahar juga dikenal sebagai pengikat. Selain itu, mahar juga dikenal sebagai tanda jadi dan ketika transaksi telah disepakati.

Kepalaku makin pening setiap mengingat ratusan juta yang sudah ayah serahkan untuk biaya koordinasi, konsolidasi partai, dan ratusan juta lainnya untuk uang muka mahar. Huh, mereka menggunakan kata 'mahar' untuk membungkus dengan mulia praktik pemerasan biasa itu! (Fatah, 2014)

Mahar sangat diperlukan partai politik. Itu disebabkan karena partai politik adalah mesin. Untuk menghidupkan "mesin”, mereka membutuhkan bahan bakar. Dan bahan bakar itu harus dibeli dengan mengeluarkan uang.

Dalam menghidupkan mesin partai, mereka harus melakukan konsolidasi dan koordinasi di semua elemen mulai dari tingkat pusat hingga desa. Semua harus digerakkan bersama-sama sehingga mencapai tujuan seperti arahan pemimpin.

Partai politik disebut “mesin” karena terdiri dari berbagai elemen yang mendukung, seperti sumber daya, logistik, dan jaringan. Untuk menghidupkan itu semua diperlukan dana yang tidak sedikit.

Untuk menghidupkan mesin partai politik, mereka tidak hanya mengandalkan dana partai saja. Mereka juga membutuhkan dana dari pihak ketiga.

Hanya saja, dalam cerpen “Jaket Ayah" menyebutkan mahar sebagai bentuk pemerasan dalam dunia politik. Ada kesan kalau mahar itu harus dibayar agar pencalonan sukses. Jika tidak ada mahar, maka tidak ada kesepakatan. Karena itulah kandidat bupati diharuskan membayar mahar tersebut.

"Ia harus menyediakan dana pemenangan partai sebesar Rp5,5 miliar. Tunai. Selambatnya diserahkan besok siang. Lalu, ia harus bersedia dipasangkan dengan calon wakil bupati yang sudah 
ditetapkan oleh pengurus pusat,“ lanjut ketua sambil menyebut nama seorang penyanyi dangdut. (Fatah, 2014)

Dalam politik juga disebagai dana pemenangan. Tidak ada dana kekalahan dalam partai politik. Dana kemenangan juga dikenal sebagai mahar politik yang harus dibayar oleh kandidat pemimpin. Mereka harus membayar jika ingin dicalonkan. Jika tidak, maka keinginan menjadi calon pemimpin akan menjadi buyar.

Lebih lanjut, sintagma lainnya adalah calon bupati yakni pencitraan, kampanye, dan terkenal. Untuk menjadi pemimpin di Indonesia membutuhkan syarat utama yakni dikenal dan terkenal. Walaupun orang yang sudah dikenal masyarakat, mereka juga membutuhkan berbagai cara untuk tetap bisa dikenal oleh masyarakat.

Meskipun belum menjadi calon resmi dari partai politik dan mendaftar ke Komisi Pemilihan Umum Daerah, Kolonel (Purn) Sangaji Putrandi sudah berkampanye. Dia memasang poster dan baleho di berbagai penjuru wilayah pemilihan. Satu tujuannya agar sang mantan kolonel itu bisa dikenal luas.

Publik perlu mengetahui siapa sebenarnya Kolonel (Purn) Sangaji Putrandi. Melalui kampanye itu, namanya akan semakin dikenal publik. Tak ada calon bupati atau calon pemimpin yang tidak melakukan kampanye. Pasalnya, kampanye merupakan suatu media untuk mengenalkan calon pemimpin.

Semangat ayah makin bergolak setelah beberapa baliho dengan wajah ayah dan ketua partai itu bermunculan di beberapa sudut kota. Terlebih-lebih setelah nama ayah, Kolonel (Purn) Sangaji Putrandi, makin sering disebut di koran lokal. (Fatah, 2014)

Dengan semakin dikenal publik, sudah bisa dipastikan Kolonel (Purn) Sangaji Putrandi semakin senang. Dia semakin di atas. Optimisme diraihnya. Rasa kemenangan di depan matanya. Semakin bersemangatlah Kolonel (Purn) Sangaji Putrandi. Hal itu nampak wajah karena politik memang menggoda.

Wajah ayah tampak makin berkilau ketika mulai jadi tamu langganan acara pamer cakap televisi lokal. Setiap kali mengantar ayah ke stasiun televisi yang lebih mirip kantor balai desa tak terurus itu, aku mengurut dada, menghitung diam-diam berapa juta rupiah yang harus ayah keluarkan untuk membeli jam siaran itu sambil pura-pura jadi narasumber tamu terhormat yang diundang.
Kampanye menjadi ruh politik. Semua politikus akan tertuju pada kampanye. Semua orang menganggap kalau kampanye adalah pesta yang harus dirayakan. Di mana pembagian uang adalah cara untuk memenangkan sebuah kontestasi. Dalam kampanye, semua program diumbang.

Kampanye belum cukup untuk menjadi seorang bupati. Dia harus melakukan pencitraan. Dalam pencitraan, maka terjadi suatu perubahan penampilan dibandingkan sebelumnya. Itu mutlak diperlukan untuk menarik simpati dari publik. Pencitraan dilakukan agar selalu mengingat dirinya. Dengan pencitraan, maka keaslian dan naturalisme dari jiwa seseorang akan berganti.

Itulah politik.

Pencitraan dianggap sebagai segalanya. Bukan hanya perubahan penampilan semata. Tapi juga perubahan karakter yang mendasar dalam diri seseorang juga akan bergeser ke tempat lain.

Tapi ayah malah sebaliknya. Lebih senang berdandan. Lebih sadar memadupadankan warna baju dan celana yang dipakainya. Lebih banyak tersenyum dan bergairah. (Fatah, 2014)

Calon bupati akan menunjukkan dirinya sebagai sebagai seseorang yang selalu tersenyum untuk menunjukkan aura kebahagiaan. Senyum itu bertujuan agar publik masih percaya kepadanya. Senyum itu memiliki makna kalau dia adalah harapan rakyat untuk bisa memimpin.

Bergairah harus ditunjukkan oleh calon bupati tanpa berpikir dia akan kalah atau menang. Gairah ditunjukkan dengan mata yang bersinar dan penampilan yang penuh percaya diri. Dengan gairah, Kolonel (Purn) Sangaji Putrandi bisa tampil sebagai calon bupati yang mumpuni dan mampu mengalahkan para pesaingnya sebelum bertanding.

Membangun keniscayaan itu sangat diperlukan untuk menentukan kalau kontestasi dan pertandingan pada pemilihan kepala daerah bisa dimenangkan oleh Kolonel (Purn) Sangaji Putrandi. Mengkonstruksi kemungkinan itu sangat dibutuhkan untuk membangun persepsi publik kalau Kolonel (Purn) Sangaji Putrandi adalah pemenang bukan sebagai pecundang yang hanya bermain curang.

Terakhir, sintagma yang paling menarik adalah keluarga. Elemen penyusun keluarga adalah perhatian, kasih sayang, dan membangun masa depan. Meskipun “Jaket Ayah” bisa dikatakan sebagai cerpen politik, namun unsur keluarga yang mendominasi dalam plot cerita tersebut.

Seseorang bisa dikatakan sebagai seorang "ayah" pastinya memiliki sebuah keluarga yang 
mendukung. Seorang ayah tidak bisa berdiri sendiri. Seorang ayah pasti memiliki istri, dan anak. Seorang ayah bisa menjadi kakek. Ayah tidak bisa dilepaskan dari keluarga.

Apa yang dilakukan oleh seroang ayah pasti akan berdampak pada anggota keluarga yang lain. Apapun prestasi seorang ayah akan menentukan kehormatan seluruh anggota keluarganya di masyarakat. Apapun yang diucapkan seorang ayah baik di keluarganya atau di masyarakat akan dikenang banyak orang menentukan harga diri keluarga.

Demikian juga yang dilakukan oleh Kolonel (Purn) Sangaji Putrandi. Ketika dia berada di usia pensiunan, purnawirawan perwira tentunya memiliki daya magnet positif dalam politik. Dia dilirik oleh partai politik untuk menjadi seorang calon bupati. Jiwa pengabdiannya dipanggil, tetapi banyak hal yang mengharuskan keluarga harus berpikir tentang pengabdian tersebut.

Bisa dikatakan, seluruh anggota keluarga Kolonel (Purn) Sangaji Putrandi menolak keinginan sang ayah untuk maju dalam pemilihan kepala daerah. Semuanya kompak. Awalnya Kolonel (Purn) Sangaji Putrandi tetap bersikeras tentang apa yang harus diperjuangkan demi kepentingan bangsa dan negara. Dia juga tidak ingin mengalami postpower syndrome atau masa jeda ketika tidak ada aktivitas berarti bagi orang yang menghadapi masa pensiun. Namun, anggota keluarganya tetap satu suara. Mereka menolak keinginan dan ambisi sang ayah yang dipengaruhi oleh para politikus busuk itu.

Salah satu penentang paling keras keinginan politik sang ayah adalah istrinya. Sebaga istri yang mendampingi ayah selama puluhan tahun, ibu memiliki perasaan dan intuisi tentang langkah tidak tepat yang dilakukan sang ayah.

Bagaimanapun ibu tidak ingin melihat kehancuran lebih dalam dari langkah sang ayah. Dia memberikan nasihat. Dia memberikan peringatan. Dan dia juga memberikan ultimatum sebagai bentuk kekecewaan. Dia juga menunjukkan bentuk protes.

Ibu yang paling keras menentang keinginan ayah.

"Sudahlah, Pak. Kita syukuri saja yang kita miliki sekarang. Ini saatnya bapak pensiun, menikmati hasil kerja keras selama ini dengan istirahat dan berpuas-puas bermain dengan cucu. Kita bisa sering mengunjungi Sari, Yusuf, dan Nilam di Jogja. Juga Sekar, Andi, dan Johan di Makassar. Berganti-ganti. Untuk apa bikin-bikin kesibukan baru?" (Fatah, 2014)
Alasan sang Ibu sangatlah sederhana. Dia ingin menghabiskan masa tuanya untuk keluarga. Bermain bersama cucu. Dia tidak ingin ada kesibukkan yang menyita waktu keluarga. Dia ingin kebahagiaan di akhir masa tuanya. Dia tidak ingin dipusing dengan banyak hal yang membuatnya repot.

Bukan hanya ibu saja yang menolak. Anak-anak Kolonel (Purn) Sangaji Putrandi juga menyatakan ketidaksetujuan dengan sikap sang ayah. Anak-anak telah mengetahui dunia politik. Dia tidak ingin sang ayah terjebak dengan dunia politik yang gelap dan penuh dengan mister.

Sari dan Sekar juga meminta ayah menimbang ulang niat untuk memenuhi ajakan ketua partai itu. "Aku enggak suka politik dan enggak pernah akan suka,“ kata Sekar lewat telepon. Sari lebih tegas, "Politik kan cuma dunia buat para penipu bermulut manis.“ (Fatah, 2014)

Aku terang-terangan menentang karena merasa paling berkepentingan. Sebab, sudah terbayang sebentar lagi aku akan jadi sopir ayah ke manamana. Akulah yang akan diandalkan ayah menemaninya berurusan dengan orang-orang partai itu. Sebagai bungsu yang menganggur, aku yang juga akan jadi bodyguard ayah dalam semua urusan ini. Menganggur? Tidak juga. Aku sedang tersendat menyelesaikan skripsi. Kelas kuliah sudah tak ada. Ke kampus hanya sesekali ketika butuh bimbingan.

Para anak Kolonel (Purn) Sangaji Putrandi telah memberikan saran terbaik untuk sang ayah. Namun, mereka tidak berdaya ketika sang ayah sudah mengambil sikap. Namun, mereka telah menunjukkan aksi mogok bicara dengan sang ayah.

Mereka telah menghindari komunikasi dengan sang ayah. Satu tujuannya untuk mengingatkan sang ayah kalau keluarga adalah segalanya. Mereka memiliki harapan kalau ayahnya berubah. Dan harapan itu pun terwujud.

Aku tak tahu, haruskah aku bersyukur atau bersedih dengan peristiwa malam itu. Duduk di samping ayah seperti biasa, aku mengikuti drama tragis yang dimainkannya. Pendaftaran calon bupati dan wakil akan ditutup seminggu lagi. Maka, pertemuan besar diadakan untuk meresmikan pengusungan partai pada ayah. Tapi pertemuan itu melenceng jauh dari harapan ayah. (Fatah, 2014)

Dalam cerpen itu diungkapkan ada sinar terang kalau sang ayah ternyata menentukan sikap yang jelas sesuai dengan keinginan keluarga. Meskipun, sang ayah harus melalui jalan yang rumit dan itu menjadi pembelajaran yang sangat berarti dalam kehidupannya. Dia memilih kehidupan keluarga. 
Dan keluarga adalah tempat kembali terbaik bagi sang ayah.

\subsection{Tanda dan Makna dalam Semiotik Sastra}

\subsubsection{Tanda dan Makna}

Ada dua tanda yang menonjol pada cerpen Jaket Ayah. Dua tanda yang sangat menonjol adalah jaket dan tabungan. Peneliti secara khusus mengupas keduanya.

Jaket menjadi benda istimewa dalam cerpen berjudul "Jaket Ayah". Penulis cerpen ini yakni pengamat politik Eep Saefulloh Fatah tampak tidak menjelaskan rinci tentang jaket tersebut. Tidak ada penjelasan tentang warna, desain, riwayat, atau seluk beluk jaket tersebut. Yang pasti, jaket itu sangat spesial untuk ayah. Jaket itu memiliki kewibawaan untuk ayah. Jaket itu memiliki riwayat istimewa tentang ayah.

Dijelaskan kalau si pemilik jaket adalah seorang pensiunan perwira. Sudah jelas kalau jaket tersebut menjadi simbol tertentu yang sangat berharga bagi pemiliknya. Bisa jadi jaket itu memiliki pangkat di pundak yang menunjukkan status dan pangkatnya. Meskipun sudah pensiun, jiwa seorang tentara akan melekat. Dia tetap dihormati para seniornya. Dia juga akan tetap disegani oleh para mantan tentara yang pernah menjadi bawahannya.

Jaket itu selalu menyambar mataku dari kaca spion di atas kepalaku yang celakanya mesti sering kulirik setiap menyopiri ayah. Menemani artinya menyopiri, memarkir kendaraan, lalu berlaku seperti ajudan ayah dalam setiap acara penggalangan. Menemani berarti juga merelakan kuping, pikiran, dan hatiku dihantam pidato demi pidato membosankan, berisi kebohongan berkedok empati pada warga yang dikumpulkan. (Fatah, 2014)

Di ceritakan dalam cerpen tersebut kalau jaket tersebut menjadi saksi dalam setiap peristiwa politik yang melibatkan ayah. Jaket itu menemani setiap pergerakan ayah. Seolah-olah diceritakan kalau jaket tersebut seolah-olah hidup. Itu menunjukkan kalau jaket tersebut mampu merekam dan melihat tentang apa yang terjadi pada ayah.

Jaket ayah seperti monumen kekalahan aku dan ibu. Jangankan saat dikenakan ayah yang selalu penuh senyum ketika memakainya. Ketika sekadar tergantung di dalam mobil saja, jaket itu seperti meledek kami dengan nyinyir. Bagiku, jaket ayah bukan hanya mengganggu mata karena warnanya yang norak, tapi juga bagai hantu buruk rupa yang menguntitku ke mana-mana. Pernah sekali waktu kulipat sehingga tak terlalu mengganggu pandangan kaca spionku, tapi ayah marah di luar dugaanku. Sejak itu, aku berusaha bersahabat dengan jaket itu. Rencana persahabatan yang gagal tapi benar-benar tak bisa kuhindari. (Fatah, 2014)

Jaket bukan hanya sekadar pakaian pelengkap saja. Namum, jaket juga menjadi penguat identitas seseorang. Jaket bisa mencerminkan orang yang memakainya. Jaket juga bisa menjsdi ciri khas yang melekat pada diri seseorang. Itu karena ayah tidak.mau melepaskan diri dari jaket tersebut.

Jaket juga bisa diartikan sebagai pelindung. Pakain memang pelindung manusia dari cuaca. Nah, khsusus jaket dipakai orang pada cauca ekstrem seperi hujan atau musim dingin. Bisa jadi ayah mengenakan jaket tersebut untuk melindungi diri dari situasi ekstrem yang sulit untuk dihindari. Dengan mengenakan jaket, dia akan merasa nyaman dan aman.

Kemudian, sebagai orang yang berpenghasilan bulanan, pasangan suami dan istri pastinya akan mempersiapkan diri untuk masa pensiun. Dana tabungan juga disiapkan Sang Kolonel untuk masa tuanya. Tentunya persiapan masa tua yang standar saja.

Suatu hari, aku mendapati ibu menangis di pojok ruang keluarga setelah ayah meminta izin, tepatnya memberi tahu ibu, untuk menggunakan dana di tabungan mereka. Ayah yang sejak sebelum purnawira tak pernah berbisnis dan hidup lurus tak punya cadangan dana selain tabungan. Ketika ia merasa terdesak untuk membiayai penggalangan sesuai desakan para pengurus partai itu, tabungan satu-satunya andalan Ayah. Jika pun ada yang lain, dua bidang tanah tak begitu luas di Lamongan, kampung halaman ibu, yang tentu tak akan mudah terjual. (Fatah, 2014)

Tidak ada persiapan sejak dulu kalau Sang Kolonel dan istri akan menyiapkan diri untuk bekal politik. Itu ditunjukan ketika sang ayah terbujuk rayu para politkus untuk masuk dalam bursa calon bupati di mana mendapatkan penolakan dari seluruh anggota keluarganya.

Aku lemas mendengar ayah akan menguras tabungannya. Aku tahu, pasti ibu yang mendampingi ayah sejak perwira muda lebih lemas lagi. Aku hanya bisa menghampiri ibu dan memeluknya. (Fatah, 2014)

“Apa gunanya 30 tahun menabung kalau mau dihamburkan untuk tiga bulan yang sia-sia...?“ Hanya keluhan yang lebih mirip lenguhan ibu ini yang menyeruput kupingku saat kami berpelukan seperti dua pohon pisang baru ditebang, yang saling condong ke depan. (Fatah, 2014) 
Kisah itu menunjukkan pesan kepada semua orang kalau dana tabungan harus digunakan untuk kepentingan terbaik yang sudah direncanakan sejak awal. Dana tabungan harus menjadi babak yang harus menentukan kehidupan baru yang menentramkan bukan menggelisahkan dan mengkhawatirkan.

\subsubsection{Semiotik dan Biografi Penulis}

Dalam kajian semiotik sastra tidak bisa dilepaskan dari biografi penulis. Cerpen "Jaket Ayah" ditulis oleh Eep Saefulloh Fattah. Dalam keterangan penulis yang ditampilkan di Harian Suara Merdeka menunjukkan kalau Eep merupakan seorang pengamat politik yang suka menulis cerita.

Sepengetahuan penulis, Eep merupakan seorang pakar politik yang memimpin lembaga konsultan politik. Dia pernah mengantarkan Anies Baswedan sebagai gubernur Jakarta. Eep juga pernah menjadi konsultan politik Joko Widodo dalam pemilu presiden 2014.

Sebagai konsultan politik, Eep sangatlah paham dengan pernak-pernik politik. Termasuk di antaranya pemilihan kepala daerah. Dia memgetahui seluk beluk tentang politik bukan hanya teori, tetapi realitas di lapangan.

Eep menuliskan cerpen politik dari ide yang sepertinya dia peroleh dari pengalamannya. Dia menyampaikan fenomena politik apa adanya dan terang benderang. Itu dimaksudkan karena cerpen bisa menjadi wahana yang tepat baginya untuk menyampaikan hal yang tidak akan terkesan vulgar. Bagaimanapun cerpen menjadi bagian sastra yang mampu menyuarakan fenomena di masyarakat.

Tidak ada yang basi dalam dunia sastra. Meskipun cerpen bertema politik diterbitkan Eep di Media Indonesia pada 2014, cerita itu tidak akan lengkang ditelan zaman. Kisah itu tetap hidup karena pemilihan kepala daerah tetap menjadi fenomena yang dihadapo masyarakat.Di mobil kami selalu tergantung sehelai jaket warna terang. Ayah menggantungnya di sana dan harus tetap di sana, tak boleh kami turunkan.

\section{KESIMPULAN}

Ada beberapa unsur sintagma dalam Cerpen Jaket Ayah karya Eep Saefulloh Fatah Unsur. Sintagma yang pertama adalah politikus partai politik sombong, tukang sulap, penuh sandiwara, mudah berkhianat, banyak siasat, dan banyak berjanji. Sintagma lainnya adalah partai politik yang terdiri dari krisis kader, calon pemimpin, orang yang bersih, dan pemilihan kepala daerah. Sintagma mahar itu berkaitan dengan biaya politik, konsolidasi dan koordinasi, serta pemerasan. Sintagma lainnya adalah calon bupati yakni pencitraan, kampanye, dan terkenal. Sintagma yang paling menarik adalah keluarga yakni penyusun keluarga adalah perhatian, kasih sayang, dan membangun masa depan.

Dua tanda yang sangat menonjol adalah jaket dan tabungan. Jaket tersebut menjadi saksi dalam setiap peristiwa politik yang melibatkan ayah. Dana tabungan harus digunakan untuk kepentingan terbaik yang sudah direncanakan sejak awal. Dana tabungan harus menjadi babak yang harus menentukan kehidupan baru yang menentramkan bukan menggelisahkan dan mengkhawatirkan. "Jaket Ayah" ditulis oleh Eep Saefulloh Fattahyang merupakan seorang pengamat politik yang suka menulis cerita.

\section{REFERENSI}

Barthes, Roland. 1973. Elements of Semiology. Terjemahan oleh Annette Lavers dan Collin Smith. New York: Hill and Wang.

Chandler, Danile. 2017. Semiotics: The Basics. New York: Routledge.

Fatah, Eep Saefulloh. Jaket Ayah. Media Indonesia, terbit 4 Mei 2014.

Kurniawan. 2001. Semiologi Roland Barthes. Magelang: Yayasan IndonesiaTera

Krampen, Martin. 1987. "Ferdinand de Saussure and the Development of Semiology". dalam Martin Krampen dkk. Classic of Semiotics. New York: Spinger Science.

Shortell, Timothy. 2016. Everyday Globalization: A Spatial Semiotics of Immigrant Neighborhoods in Brooklyn and Paris. New York: Routledge.

Simpkins, Scott. 2001. Literary Semiotics: A Critical Approach. Maryland: Lexington Books.

Veiovo, Harri, dkk. 2009. Redefining Literary Semiotics. Newcastle: Cambridge Scholars Publishing.

\section{PROFIL PENULIS}

Andika Hendra Mustaqim merupakan dosen Akademi Bahasa Asing Bina Sarana Informatika (BSI) Jakarta. Dia mengampu mata kuliah penerjemahan, penulisan akademik, dan sastra. Selain mengajar, Andika, demikian nama panggilannya, juga bekerja sebagai redaktur desk internasional di KORAN SINDO. Andika menempuh pendidikan program sarjana Sastra Inggris di Universitas Brawijata dan melanjutkan pendidikan 
pascasarjana dalam bidang Linguistik Terapan di Universitas Negeri Jakarta. Andika juga telah merilis novel berjudul Indonesia Berkerabat pada Desember 2017 lalu. Dia pernah mendapatkan dua kali hibah Penelitian Dosen Pemula dan meraih Hibah Penulisan Buku Ajar dari Kementerian Riset dan Pendidikan Tinggi. Penulis bisa dihubungi melmelalui posel andika.ahq@bsi.ac.id, akun Twitter@andikahendra, dan akun Instagram @andikahendramustaqim. 